\title{
Gambaran Stres Akademik Mahasiswa Asal Papua di Provinsi Sumatera Barat
}

\author{
Muhammad Hasbi', Nila Anggreiny'2, Yantri Maputra ${ }^{3}$ \\ 1, 2, 3 Program Studi Psikologi Fakultas Kedokteran Universitas Andalas, Padang \\ A B S T R A C T
}

\begin{abstract}
Latar Belakang. Mahasiswa asal Papua yang berkuliah di Provinsi Sumatera Barat dituntut untuk mampu beradaptasi, bukan hanya beradaptasi dengan lingkungan sosialnya, tetapi juga beradaptasi dengan kehidupan akademiknya. Mahasiswa Papua merasa bahwa beban dan tuntutan akademik yang diterima membebani dan menimbulkan masalah bagi kehidupan akademiknya. Stres akademik adalah keadaan tertekan yang dialami oleh individu karena tuntutan dan beban akademik yang melebihi kemampuan individu yang tidak dapat diatasi oleh individu tersebut.
\end{abstract}

Objektif. Penelitian ini bertujuan untuk melihat sumber utama stres akademik dan tingkat stres akademik mahasiswa asal Papua di Provinsi Sumatera Barat.

Metode. Penelitian ini menggunakan metode kuantitatif deskriptif. Variabel yang diukur dalam penelitian ini adalah stres akademik. Teknik pengambilan sampel yang digunakan adalah teknik accidental sampling, dimana semua sampel yang ditemui dan bersedia dijadikan sebagai sampel penelitian yaitu sebanyak 53 orang mahasiswa. Pada penelitian ini, stres akademik diukur dengan menggunakan Academic Stress Inventory of Students dari Lin dan Chen (2009) yang terdiri dari tujuh sumber stres yang tersebar menjadi 34 item dengan koefisien reliabilitas sebesar 0,944 .

Hasil. Hasil penelitian ini menunjukkan bahwa tingkat stres akademik mahasiswa asal Papua berada pada kategori tinggi dan yang menjadi sumber utama stres akademik mahasiswa asal Papua di Provinsi Sumatera Barat adalah pengajar.

Kesimpulan. Mahasiswa asal papua yang dominan memiliki stress adalah jenis kelamin laki-laki dan berada di semester satu. Sumber utama mereka stress dari pengajar.

Kata kunci: mahasiswa papua, stres, stres akademik

Background. Students from Papua who are studying in West Sumatera province are required to adapt, not only adapt to their social environment but also adapt to academic life. Papuan students feel that the burden and academic demands that are received are burdensome and cause problems for his academic life. Academic stress is a depressed state experienced by individuals because of demands and academic burdens that exceed individual abilities that the individual cannot overcome.

\begin{abstract}
Objective. This research aims to see the main source of academic stress and academic stress level of students from Papua in West Sumatera province.
\end{abstract}

Methods. This research uses a descriptive quantitative method. The variables measured in this study were academic stress. The sampling technique used is an accidental sampling technique, where all the samples found and willing as research samples of 53 students. In this study, academic stress was measured using the Academic Stress Inventory of Students from Lin and Chen (2009) consisting of seven sources of stress spread to 34 items with a reliability coefficient of 0.944 .

Results. The results showed that the academic stress level of students from Papua is in the high category and which is the main source of student academic stress from Papua in West Sumatera province is the teacher.

Conclusion. Students from Papua who are predominantly stressed are male and are in semester one. Their main source of stress is from teachers.

Keywords: Papuan students, stress, academic stress

\section{Apa yang sudah diketahui tentang topik ini?}

Mahasiswa Papua merasa bahwa beban dan tuntutan akademik yang diterima membebani dan menimbulkan masalah bagi kehidupan akademiknya. Stres akademik adalah keadaan tertekan yang dialami oleh individu karena tuntutan dan beban akademik yang melebihi kemampuan individu yang tidak dapat diatasi oleh individu tersebut.

\section{Apa yang ditambahkan pada studi ini?}

Tingkat stres akademik mahasiswa asal Papua berada pada kategori tinggi dan yang menjadi sumber utama stres akademik mahasiswa asal Papua di Provinsi Sumatera Barat adalah pengajar.

\section{CORRESPONDING AUTHOR}

\section{Phone: 082170203640}

E-mail:muhammadhasbi2210@gmail.com

ARTICLE INFORMATION

Received: March $12^{\text {th }}, 2020$

Revised: March $16^{\text {th }}$, 2020

Available online: March $20^{\text {th }}, 2020$ 


\section{Pendahuluan}

Papua hingga saat ini masih kurang memperoleh akses pendidikan yang baik, terutama pendidikan tinggi. Untuk itu, diadakan upaya percepatan dan pemerataan pendidikan di Papua, khususnya pendidikan tinggi. Salah satu upaya tersebut, yaitu program keberpihakan pemerintah atau Program Afirmasi Pendidikan Tinggi yang disingkat dengan program ADik.

Di Sumatera Barat, ada dua perguruan tinggi negeri dan dua politeknik negeri yang menerima peserta beasiswa ADik. Perguruan tinggi dan politeknik tersebut ialah Universitas Andalas, Universitas Negeri Padang, Politeknik Negeri Padang dan Politeknik Pertanian Negeri Payakumbuh. Mereka yang menimba ilmu di jenjang pendidikan tinggi, termasuk anak Papua yang menerima program ADik ini, disebut dengan mahasiswa ${ }^{1}$.

Mahasiswa Papua yang berkuliah di luar daerah, terutama Provinsi Sumatera Barat pasti akan mengalami berbagai perubahan karena adanya perbedaan dari daerah asalnya. Perubahan-perubahan tersebut, seperti perubahan bahasa, kebudayaan dan lingkungan yang berbeda, perubahan pola kehidupan yang jauh dari keluarga maupun perubahan program pendidikan yang menuntut mereka mampu beradaptasi dengan lingkungan baru. Mahasiswa asal Papua yang tidak mampu menyesuaikan diri dengan beraneka perubahan yang dialami tentu akan menimbulkan berbagai permasalahan dan kesulitan pada dirinya.

Kesulitan yang sering dialami oleh mahasiswa perantau saat pertama kali tinggal di tempat baru adalah perbedaan bahasa $^{2}$. Dari hasil pengumpulan data awal yang peneliti lakukan terhadap mahasiswa Papua pada tanggal 23 Januari 2019, kendala utama yang mereka hadapi adalah masalah komunikasi, baik dalam lingkungan sosial maupun dalam perkuliahan. Beberapa staf pengajar memasukkan bahasa daerah kedalam materi yang disampaikan di depan kelas sehingga mahasiswa Papua mengalami masalah dalam memahami materi. Mahasiswa Papua pada awalnya merasa kesulitan dengan bahasa yang digunakan oleh teman kampus, dosen, dan masyarakat di lingkungannya. Mereka merasa tidak paham dengan materi yang disampaikan oleh dosen ketika dosen tersebut menyelipkan bahasa Minang dalam materi yang disampaikan ${ }^{3}$.

Lebih lanjut, kendala lain yang dialami mahasiswa Papua sehingga mengganggu pendidikan ialah ketidakmampuan dalam menggunakan teknologi dan presentasi di depan kelas guna memaparkan tugas yang diberikan dosen. Kesulitan dalam presentasi ini, seperti pemilihan dan penggunaan redaksi yang tidak tepat sehingga membuat mahasiswa Papua tidak percaya diri, baik saat tampil di depan kelas maupun aktif dalam diskusi kelompok. Selain itu, mereka juga mengalami kesulitan untuk menyampaikan gagasan yang dimiliki, terlebih dengan sistem pendidikan yang menganut Student Centre Learning (SCL). Hal ini membuat tidak sedikit mahasiswa Papua yang merasa takut gagasannya tidak sesuai dan tidak diterima oleh dosen dan teman sekelasnya.

Masalah-masalah yang dihadapi di atas tentu saja dapat menyebabkan stres. Hal tersebut karena banyaknya tuntutan akademik yang harus dihadapi mahasiswa, seperti ujian, tugas-tugas dan lain sebagainya ${ }^{4}$. Sejumlah peneliti telah menemukan bahwa mahasiswa yang mengalami stres akan cenderung menunjukkan kemampuan akademik yang menurun ${ }^{4}$, kesehatan yang memburuk $^{5}$, depresi ${ }^{6}$, dan gangguan tidur ${ }^{7}$.

Stres akademik merupakan suatu keadaan dimana terdapat permasalahan akademik, rasa frustasi dan permasalahan di kampus yang disebabkan oleh ketidakmampuan individu dalam menyesuaikan diri, tidak bahagia dan mengalami masalah fisik dan mental ${ }^{8}$. Stres akademik ini memiliki dua faktor, yaitu faktor internal yang bersumber dari diri atau pribadi individu seperti kepribadian, locus of control, dan efikasi diri dan faktor eksternal, seperti faktor lingkungan rumah, lingkungan belajar dan lingkungan masyarakat ${ }^{9}$.

Stres akademik dapat menimbulkan dampak kegelisahan, kegugupan, gangguan pencernaan, kekhawatiran yang tidak ada habisnya, tegang, nyeri di leher atau bahu10. Peningkatan stres akademik berpengaruh terhadap indeks prestasi. Beban stres yang dirasa terlalu berat dapat memicu gangguan memori, konsentrasi, penurunan kemampuan penyelesaian masalah, dan kemampuan akademik ${ }^{11}$. Hal ini selaras dengan data yang peneliti peroleh dari pusat informasi kampus yang ada di Sumatera Barat, dari total 85 orang mahasiswa asal Papua, hanya 
14 orang yang memiliki IPK di atas 3,00, sebanyak 9 orang memilih untuk berhenti berkuliah di Sumatera Barat dan kembali pulang ke kampung halamannya untuk melanjutkan kuliah di sana atau bekerja. Oleh karena itu, berdasarkan pemaparan fenomena dan uraian penelitian terdahulu, peneliti tertarik untuk melihat tingkat stres akademik dan sumber stres akademik yang dialami oleh mahasiswa asal Papua yang berkuliah di Provinsi Sumatera Barat.

\section{Metode}

Metode yang digunakan dalam penelitian ini adalah metode kuantitatif deskriptif dengan variabel tunggal, yaitu stres akademik. Penelitian ini menggunakan Academic Stress Inventory of Students yang dirancang oleh Lin dan Chen (2009) yang terdiri dari 34 item. Teknik sampling yang digunakan accidental sampling dengan jumlah sampel sebanyak 53 orang mahasiswa asal Papua yang kuliah di Provinsi Sumatera Barat.

\section{Hasil}

Hasil pengolahan skor hipotetik menunjukkan bahwa secara umum tingkat stres akademik mahasiswa asal Papua yang berkuliah di Provinsi Sumatera Barat berada pada kategori tinggi dengan jumlah mahasiswa sebanyak 40 orang. Sedangkan untuk mahasiswa yang berada pada kategori rendah berjumlah sebanyak 13 orang. Jika dilihat dari sumber stres akademik, sumber yang paling tinggi menyebabkan stres adalah pengajar, sedangkan yang paling rendah ditunjukkan oleh sumber stres dari hasil. Jika dilihat gambaran berdasarkan jenis kelamin, rumpun jurusan dan semester, didapatkan hasil sebagai berikut:

Tabel 1. Hasil Penelitian

\begin{tabular}{lccc}
\hline \multicolumn{1}{c}{ Karakteristik } & $\mathbf{f}$ & $\mathbf{\%}$ & Skor Mean \\
\hline Jenis Kelamin & & & \\
$\quad$ Laki-laki & 22 & $41,5 \%$ & 3,30 \\
$\quad$ Perempuan & 31 & $58,5 \%$ & 3,16 \\
Rumpun Jurusan & & & \\
SAINTEK & 32 & $60,4 \%$ & 3,18 \\
SOSHUM & 21 & $39,6 \%$ & 3,28 \\
Semester & & & \\
1 & 5 & $11,3 \%$ & 3,38 \\
3 & 17 & $32,1 \%$ & 3,33 \\
5 & 14 & $26,4 \%$ & 3,20 \\
7 & 14 & $26,4 \%$ & 3,01 \\
9 & 2 & $3,8 \%$ & 3,36 \\
\hline
\end{tabular}

\section{Diskusi}

Hasil analisis statistik stres akademik mahasiswa asal Papua yang berkuliah di Provinsi Sumatera Barat menunjukkan bahwa tingkat stres akademik mahasiswa asal Papua yang berkuliah di Provinsi Sumatera Barat berada pada kategori tinggi. Hal ini menandakan bahwa mahasiswa asal Papua merasa tertekan dengan tuntutan dan beban akademik yang diberikan oleh dosennya, sehingga mahasiswa asal Papua tidak mampu menyelesaikan tugas dan menyerap materi secara maksimal. Indikasi lain yang terlihat dari mahasiswa asal Papua adalah adanya kekhawatiran dalam menghadapi ujian yang disebabkan oleh ketidakmampuannya dalam memahami materi yang diberikan dosen dan mempersiapkan diri secara matang dengan materi yang bervaraisi. Stres akademik merupakan hasil kombinasi dari tuntutan akademik yang melebihi sumber daya individu yang tersedia untuk menghadapi tuntutan tersebut ${ }^{12}$.

Sementara itu, berdasarkan hasil analisis sumber stres akademik yang dilakukan pada mahasiswa asal Papua yang berkuliah di Provinsi Sumatera Barat, didapatkan hasil bahwa sumber utama stres akademik mahasiswa asal Papua adalah pengajar. Sumber stres dari pengajar ini merupakan stres yang timbul karena materimateri yang disampaikan oleh dosen, sistem dan metode pengajaran dan bentuk-bentuk tugas yang diberikan ${ }^{8}$.

Mahasiswa asal Papua yang berkuliah di Sumatera Barat mengutarakan bahwa mereka merasa jika tugas yang diberikan oleh dosen terlalu banyak. Ini sejalan dengan penelitian yang mengatakan bahwa stres akademik mahasiswa disebabkan oleh beban akademik seperti pekerjaan rumah (penugasan) yang sangat banyak atau tidak jelas ${ }^{13}$.

Banyaknya materi yang disampaikan oleh dosen juga memicu timbulnya stres akademik. Hal ini tergambar pada mahasiswa asal Papua yang mengatakan jika materi yang disampaikan dosen terlalu banyak sehingga mereka sulit untuk menyerap pelajaran dan menyebabkan sebagian materi yang dosen berikan tidak mampu mereka terima dengan baik. Hal lain yang juga dirasa semakin membuat mereka tidak mampu menyerap materi yang diajarkan dosen adalah materi-materi yang menggunakan istilah dengan menggunakan bahasa asing dan bahasa daerah. 
Selain materi yang menggunakan bahasa asing dan bahasa daerah, mahasiswa asal Papua merasa kurang mampu untuk menyesuaikan diri dengan metode pengajaran yang digunakan oleh dosen sehingga mereka merasa bermasalah dalam menerima materi ajar tersebut. Stres akademik bersumber pada tuntutan tugas-tugas akademik dan tuntutan dari pengajar. Ketidakmampuan mahasiswa dalam menyesuaikan diri dengan tuntutan dari dosen akan menyebabkan mahasiswa tersebut tertekan ${ }^{14}$.

Selanjutnya, berdasarkan analisis statistik menunjukkan bahwa skor paling rendah diperoleh oleh sumber stres dari hasil. Hal ini menunjukkan bahwa hasil belajar dan ujian yang diperoleh oleh mahasiswa asal Papua yang berkuliah di Provinsi Sumatera Barat tidak terlalu membuat mereka merasa tertekan. Stres karena hasil ini bersumber dari orang tua, konflik antara ekspektasi dan pikiran, serta kegagalan dalam perkuliahan $^{8}$.

Melihat hubungan dengan orang tua, mahasiswa Papua merasa tidak ada konflik dan tuntutan hasil yang menekan dari orang tua. Orang tua tidak mempermasalahkan hasil yang didapatkan oleh mahasiswa asal Papua yang berkuliah di Provinsi Sumatera Barat. Mahasiswa asal Papua mengatakan bahwa dengan diterimanya mereka sebagai mahasiswa melalui beasiswa ADik, sudah melebihi harapan dari orang tuanya, sehingga orang tua tidak memasang target capaian hasil yang harus diperoleh oleh mahasiswa asal Papua. Namun, hal yang cukup dirasakan oleh mahasiswa asal Papua adalah perbedaan hasil akademik yang mereka peroleh sewaktu kuliah dengan hasil akademik semasa SMA. Mahasiswa asal Papua merasa bahwa hasil yang diperoleh di perkuliahan tidak sebagus hasil yang didapat ketika berada di tingkat SMA.

Jika dilihat berdasarkan jenis kelamin mahasiswa asal Papua, hasil pengolahan skor ratarata menunjukkan bahwa laki-laki mengalami stres akademik yang lebih tinggi jika dibandingkan dengan perempuan. Hal ini sejalah dengan penelitian yang dilakukan pada mahasiswa di Taiwan yang mengatakan bahwa laki-laki memiliki tingkat stres akademik yang lebih tinggi dibanding dengan perempuan ${ }^{15}$. Ditambahkan juga oleh hasil penelitian yang dilakukan terhadap mahasiswa di Nigeria yang menunjukkan bahwa laki-laki memiliki skor stres akademik lebih tinggi dibandingkan skor stres akademik perempuan ${ }^{16}$.

Berdasarkan rumpun jurusan yang ditempati mahasiswa asal Papua, hasil analisis menunjukkan bahwa mahasiswa rumpun jurusan SOSHUM lebih mengalami stres akademik dibandingkan dengan mahasiswa rumpun jurusan SAINTEK. Hal ini bertolak belakang dengan hasil penelitianyang mengatakan bahwa mahasiswa kedokteran cenderung mengalami stres akademik yang tinggi jika dibandingkan dengan program studi lain di sektor non-medis ${ }^{17}$.

Jika dilihat dari semester yang sedang dijalani oleh mahasiswa asal Papua, skor rata-rata mahasiswa asal Papua menunjukkan bahwa mahasiswa semester satu mengalami stres akademik paling tinggi. Hasil yang sama juga ditunjukkan oleh penelitian yang mengatakan bahwa stres akademik mahasiswa semester baru paling tinggi dan akan menurun seiring meningkatnya semester yang dilalui, hal ini normal terjadi karena merupakan bagian perkembangan diri seperti menyesuaikan diri dengan tatanan sosial baru, mendapatkan peran dan tanggung jawab baru sebagai mahasiswa, mempunyai beban belajar dan konsep - konsep pendidikan yang berbeda dengan masa sekolah sebelumnya ${ }^{18}$.

\section{Kesimpulan}

Tingkatan stres akademik mahasiswa asal Papua yang berkuliah di Provinsi Sumatera Barat secara umum berada pada kategori tinggi. Berdasarkan sumber stres akademik, didapati bahwa sumber utama stres akademik mahasiswa asal Papua yang berkuliah di Provinsi Sumatera Barat bersumber dari pengajar. Berdasarkan jenis kelamin, stres akademik mahasiswa asal Papua yang berkuliah di Provinsi Sumatera Barat dengan jenis kelamin laki-laki lebih tinggi daripada mahasiswa yang berjenis kelamin perempuan. Berdasarkan semester yang sedang ditempati, mahasiswa asal Papua yang berkuliah di Provinsi Sumatera Barat yang sedang menempati semester satu mengalami tingkat stres akademik yang lebih tinggi daripada semester yang lainnya.

\section{Ucapan Terima Kasih}

Terima kasih kepada semua pihak yang telah membantu dalam pelaksanaan penelitian ini. 


\section{Daftar Pustaka}

1. Republik Indonesia. (2012). Undang-undang Republik Indonesia Nomor 12 tahun 2012 tentang Pendidikan Tinggi. Jakarta: Sekretariat Negara.

2. Niam, E. K. (2009). Koping terhadap stress pada mahasiswa luar Jawa yang mengalami culture shock di Universitas Muhammadiyah Surakarta. Indegenius: Jurnal Ilmiah Berkala Psikologi, 11(1), 112.

3. Illahi, R. (2017). Penyesuaian diri mahasiswa Papua yang kuliah di Universitas Andalas. Dalam Skripsi Prodi Psikologi Fakultas Kedokteran. Padang: Universitas Andalas.

4. Rafidah, K., Azizah, A., Norzaidi, M. D., dkk (2009). Stress and academic performance: Empirical evidence from university students. Academy of Educational Leadership Journal, 13(1), 37-51.

5. Chamber, M. J., \& Curral, L. (2005). Stress in academic life work characteristic as the prediction of student well-being and performance. Journal Applied Psychology, 54(1), 135-147.

6. Das, P. P. P., \& Sahoo, R. (2012). Stress and depression among post-graduate students international. Internasional Journal And Research Publication, 2(7), 1-5.

7. Waqas, A., Khan, S., Sharif, W., dkk (2014). Association of academic stress with sleeping difficulties in medical students of a Pakistan Medical School: A cross-sectional survey. Peer Journals, 2(698), 1-11.

8. Lin, Y. M., \& Chen, F. S. (2009). Academic stress inventory of students at universities and colleges of technology. World Transaction on Engineering and Technology Education, 7(2), 1-6.

9. Cooper, C.L. \& Davidson, R. (1991). Personality and stress: Individual differences in the stress process. New York: John Wiley and Sons Ltd.

10. Agolla, J. E., \& Ongori, H. (2009). An assessment of academics stresses among undergraduate students. Academic Journal, Educational Research, and Review, 4(2), 063-070.

11. Goff, A. M. (2009). Stressor, academic performance, and learned resourcefulness in baccalaureate nursing students. International Journal of Nursing Educational Scholarship, 8(1), 1-13.

12. Wilks, S. E. (2008). Resilience amid academic stress: The moderating impact of social support among social work students. Advances in Social Work, 9(2), 106-125.

13. Misra, R., Mckean, M., West, S., \& Russo, T. (2000). Academic stress of college students: Comparison of student and faculty perceptions. College Student Journal, 16, 41-51

14. Desmita. (2011). Psikologi perkembangan peserta didik. Bandung: Remaja Rosdakarya.

15. Kai-Wen, C. (2009). A study of stress sources among college students in Taiwan. Journal of Academic and Business Ethics, 2(3), 1-8.

16. Busari, A. 0. (2012). Identifying differences in perceptions of academic stress and reactions to stressors based on gender among first-year university students. International Journal of Humanities and Social Science, 2 (14), 138 - 146

17. Navas, S. (2012). Stress among medical students. Kerala Medical Journal, 5(2), 1-12.

18. MacGeorge, E. L., Samter, W., \& Gillihan, S. J. (2005). Academic stress, supportive communication, and health. Communication Education, 54(4), 365-372. 